Kogut-Jaworska, M. (2018). Principles of support for the common good services co-financed from public financial means. Copernican Journal of Finance \& Accounting, 7(1), 9-19. http://dx.doi. org/10.12775/CJFA.2018.001

\author{
Magdalena Kogut-JaWorska* \\ University of Szczecin
}

\title{
PRINCIPLES OF SUPPORT FOR THE COMMON GOOD SERVICES CO-FINANCED FROM PUBLIC FINANCIAL MEANS
}

Keywords: public finance, self-government units, common good services, local finance.

J E L Classification: F42, F63, H41, H87.

\begin{abstract}
Territorial self-governments of all levels (commune, county or region) perform services for the common good which, for obvious reasons, are conditioned by the financial system of the self-government units. The Constitution of the Republic of Poland states that common good services which cover the needs of the community are performed by self-government units as their own tasks. However, the level of diversification of the common good services assigned to self-government units, it changes over time. In addition, the self-government itself most often deals with the realization of the tasks given (within its own organizational structure or through the system of self - governmental financial agencies, own communal partnerships and those in which it has a stake). The self - government can also place orders with other business entities which have adequate means to meet the requirements. Such state of affairs creates a need to make analyses of the implementation systems of the duties assigned to the territorial self-government units in Poland. The analyses will indicate which tasks are the most expensive ones, and will show opportunities for their implementation by the subjects which are adequately prepared (within the procedure of ordering and subsidizing of the tasks). In the above mentioned context, the goal of this paper refers to basic questions related to the obligation of supplying common good services by the territorial
\end{abstract}

Date of submission: May 16, 2018; date of acceptance: June 6, 2018.

* Contact information: magdalenakogutjaworska@gmail.com, Faculty of Management and Economics of Services, University of Szczecin, Cukrowa 8, Szczecin, Poland, phone: 504193 110; ORCID ID: http://orcid.org/0000-0001-8812-374X. 
self-government units in Poland. Another particular objective of the paper is to analyse the rules of support for common good ventures, when the aid is given from public financial resources.

\section{INTRODUCTION}

Territorial self-government units perform own tasks in order to meet the needs of the local community. In particular, they implement tasks referring to the common good, which are aimed at the current and continuous meeting the needs of the population by supplying availability of the common services (Wollmann, 2014, pp. 50-60). Those services, which in the past where rendered by the state or territorial self-government structures, now are becoming more and more privatized. It means that activities of public agencies are becoming narrower over time and that state agencies are acting according to free market rules and undergo stricter controlling procedures at public aid distribution.

The scope of tasks ascribed to the territorial self-government in Poland has been undergoing many transformations. Generally speaking, each such change broadened that scope. The 1990 Act on Municipalities gave if large responsibilities in urban planning, infrastructure development including local roads, bridges and public transport, utilities (water and sewage supply and waste management, and since 2013 energy), municipal housing, social services (including family benefits since 2004), primary education, environmental protection, basic healthcare, recreation and culture. Counties are responsible for local issues not ascribed to municipalities and have a more limited role and influence (Kańduła, 2017, pp. 804-810). Their responsibilities include secondary education, public health services (main hospitals), social welfare (beyond municipal territorial boundaries), economic activity and job creation (employment offices). Regions are responsible for issues of regional importance (determined by the law), playing a relatively limited role in providing public services (Godfrey, 2001, p. 504, 505). Their main responsibilities are regional economic development, regional roads and public transport (including railways since 2009), higher education, health (regional hospitals), social welfare, labour market and environmental protection (since 2009), etc. (www1).

However, the topic of this paper does not cover all range of solutions applied within the system of task implementation by territorial self-government units and is limited to a partial description which deals with relatively small, but 
practically very important solutions, i.e. those ones that concern common good and are covered by financial compensation.

\section{REALISATION OF COMMON GOOD TASKS AND SERVICES - THE CORE ISSUES AND METHODOLOGICAL ASSUMPTION}

The problems of realisation and financing of territorial self-government activities is an issue frequently described in the literature related to the subject (Stiglitz \& Rosengard, 2015, p. 960; Birkland, 2016; West, Berman, Bowman \& Van Wert, 2015; Ross, 2014; Tsekosand \& Triantafyllopoulou, 2016). The issue is also referred to in the Polish literature (Jastrzębska, 2012, p. 284; Patrzałek, 2010, p. 315; Swianiewicz, 2011, p. 358; Brzozowska, Gorzałczyńska-Koczkodaj, Kogut-Jaworska \& Zioło, 2013, p. 285; Maśloch \& Sierak, 2013; Sierak \& Górniak, 2013, p. 150). The dominating view stresses that the measure of activity at the task realisation is the level of expenditures. Other measures of the self-governmental activity are also referred to, in particular, those related to the basic budget measures such as: own income, operational surplus, current expenditures and expenditures on property. The following part of this paper introduces the analysis of financial conditions existing within the framework created for the common good activity of the territorial self - government in Poland, as well as it describes the main principles for the realization of the ventures connected with the activity mentioned above. The analysis is based on the current legal order, i.e., the rules of the European and Polish law. The focus is concentrated on solution applied within the system of realization and financing of the tasks for the territorial self-government units, and in particular the way of financing through compensations, with a relation to the rules of public aid.

The author applies methodological tools of theoretical analysis in particular: a selection of theoretical and descriptive material on the subject, as well as detailed comments and comparison of the present laws and regulations. Usefulness of the concepts and applicability of legal regulations were considered to understand fully the procedures to be applied for financing the common good tasks. The empiric data shown in the paper is based on material from secondary sources, namely public organizations such as: The Organization for Economic Co-operation and Development (the OECD) and the Office of Competition and Consumer Protection (the UOKiK).

A survey of empiric research indicates clearly certain specifics of self-governmental expenditure and its influence on social and economic development. 
In Poland, the specifics shows that the main goal of the expenditure is education, as self-government units are responsible for both capital and current expenditure including staff remuneration. Education is followed by healthcare and transport (weighing similarly in self-government units expenditure), and then by social welfare. In addition, self-government units are responsible for the large majority of overall public spending in the areas of environmental protection, housing and community amenities and as well as recreation and culture (over $75 \%$ of public spending) (figure 1 ).

Figure 1. Self-government Expenditure by function (in \%)

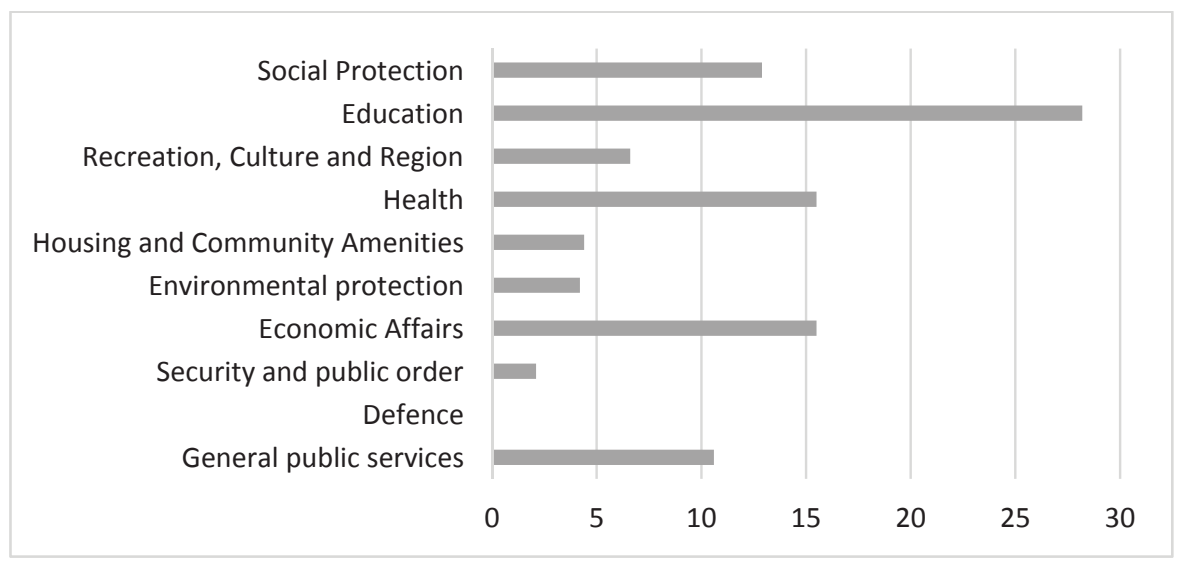

S o u r c e : own research based on: www1.

The territorial self-government, acting within its constitutional powers, provides the society with services of a particular character, namely those which can not be delivered or secured by market forces (Marcou, 2016, pp. 13-20). Public services, which in the legal framework on public aid have a leading role, are described by the Polish Legislation as own tasks, services for the common welfare or services provided for the common economic interest. In the European regulations, there appear various closely related definitions which are often applied interchangeably, i.e.: public services, services for public good, services provided for the common welfare, services for the general economic welfare, or services of non-economic character provided for the common good (differences and similarities in definitions describing these notions are presented more broadly in the book by (Ząbkowicz, 2016, p. 105). Leaving the above differences 
aside, it needs to be said that the core meaning of "services of common welfare" was first mentioned clearly at an institutional level of the European Community in the document on these services presented in Cannes (France) in 1995 (Services of General Interest in Europe). Then, the issue was given a rank of an important subject for resolutions of the treaty of Amsterdam in 1997, where, under a narrowed term: "services provided in general economic interest", the services were included into values of crucial importance for supporting the social and territorial cohesion of the whole European Union (Ząbkowicz, 2016, pp. 106, 107).

\section{PUBLIC AID AND PROTECTION FOR COMMON GOOD SERVICES}

The services of general interest have particular importance among other common services, provided for the general public and receive special protection and support. The regulations allow there for greater public aid for service providers, enhancing their profitability (Parliamentary Act of 27/08/2009 on public finance). On the other hand, the services provided without interventionism have other prices or quality levels or are not offered at all. All. The services need to be provided in accordance with the required rules and conditions, particularly in cases when the providers receive, a compensation, i.e., a financial support given by local or state administration, which covers the whole or a part of particular cost elements - according to the liabilities taken by the providers. Moreover, it is assumed that in some cases, the services can be provided only when the administration organs offer compensation to the provider.

Territorial self - government units in Poland bear the broadest scope of responsibility for availability of general interest services for the local community. In particular, the communes are burdened with the duty to maintain services necessary to meet the needs of the public in a uninterrupted way (NIK, 2015). The fulfilment of the tasks can be performed through providing services of common availability, in most cases based on the concept of services of general economic interest. In order to achieve that goal, the communes were ascribed competence to set up organizational entities, such as self-governmental budgetary units or business partnerships, and to make deals with other subjects. As the presented data show, the dynamics of support for such activities given by the communal agencies has been incremental year after year.

Services of general economic interest must be based on principles and conditions that enable complete realization of the goals to be achieved. Some of 
the services can be rendered by public enterprises, but other services by the private ones, even without substantial financial support from agencies of the member states (Yurchenko \& Lethbridge, 2014; Kuhlmann \& Fedele, 2010, pp. 49-69). Some other services can be rendered only when given financial aid by the agency responsible. When specific European Union regulations are lacking, the member states are free to establish the ways of organization and financing of the services in question.

The particular principles according to which the financing for the general interest services can be provided are set by the Decision of the Commission of 20/12/2011on the application of article 106, section 2 of the Treaty on the European Union Functions which specifies the position of the states regarding compensation for providing services of general interest. The compensation is allotted to companies obliged to render services of general economic interest (Official Journal of the EU L7 of 11/01/2012), later called The European Commission Decision 2012/21/UE, mentioned also in the official Communique of the Commission - the Principles of the European Union concerning state aid in the form of compensation for rendering services of general interest (Official Journal of the EU C 8 of 11/01/2012), also known as the Framework Rules of the European Commission 2012/C8 /03.

The formula of covering the costs of the service rendered needs to be assessed in accordance with the legal framework and the rules referring to public aid. Public aid is defined as benefits which are accorded to enterprises directly or indirectly, from the state resources or the resources of the territorial selfgovernment units. The aid for the companies features better conditions than those offered by the financial markets (economic advantage).

Besides, the support has a selective character (it privileges a certain company or companies, or production of specific goods). It threatens to distort or distorts competition and influences trade between the EU member states. The public aid, including the one from the territorial self-government units, can take various forms e.g.: subsidies, tax exemptions or reductions or any other (compare: table 1). Public aid, as an activity which distorts competition, is disallowed in the common market. However, the EU legislators have established exemptions from the rule. 
Table 1. The amount and forms of support compensating realization of general interest services

\begin{tabular}{|c|c|c|c|}
\hline Agencies allotting support & Amount of aid & Subsidies & $\begin{array}{l}\text { Amount } \\
\text { of aid mln PLN }\end{array}$ \\
\hline $\begin{array}{l}\text { National Council for Radio } \\
\text { and TV Broadcasting }\end{array}$ & 750 & & \\
\hline \multirow[t]{5}{*}{ Mayors of towns and district } & \multirow[t]{5}{*}{97.7} & compensation & 54.7 \\
\hline & & subsidies & 40 \\
\hline & & preferential loans & 2.8 \\
\hline & & $\begin{array}{l}\text { leasing of state or self-governmental pro- } \\
\text { perty (including associations of self-govern- } \\
\text { ments) to enterprises at preferential rates, } \\
\text { i.e. lower than the market ones. }\end{array}$ & 0.1 \\
\hline & & exemptions from taxes or fees & 0.04 \\
\hline Tax authorities & 10.5 & subsidies & 10.5 \\
\hline $\begin{array}{l}\text { Minister of Administration } \\
\text { and Digitalization }\end{array}$ & 0.2 & subsidies & 0.2 \\
\hline total & \multicolumn{3}{|l|}{858.4} \\
\hline
\end{tabular}

S o u r c e : UOKIK, 2016.

\section{FINANCING OF COMMON GOOD SERVICES IN THE CONTEXT OF PUBLIC AID}

Financing of services rendered for general economic interest takes usually a form of compensation paid by a public subject. The compensation cover costs which the provider of services would not have paid if it hadn't been burdened with obligations to perform particular tasks. Such situations happen in case of contracts signed by communes with municipal or private companies which provide certain services, e.g.: waste management and utilization or public transport. According to the adopted doctrine, public aid which can support services provided in the general economic interest is based on four assumptions (European Commission, 2003):

- Firstly, the benefiting enterprice must be really burdened with obligations aimed at rendering public services and the obligations should be clearly defined.

- Secondly, the parameters which are the basis for calculating the compensation must be stated in advance in a fair and objective way, so that the compensation does not create an additional economic benefit, which 
in turn, may create a privileged position of the beneficiary towards its competition. Member states which compensate losses incurred by a company without prior setting parameters of such compensation, in particular when the services rendered to the public were not financially or economically rational, can be blamed for financial interventionism that is included into ineligible state aid according to article 107 , section 1 , of the Treaty.

- Thirdly, the compensation can not exceed the necessary amount which covers, totally or partially, the costs incurred in order to meet obligations aimed at providing services of general interest (also known as public services), after having taken into consideration the relevant turnover and reasonable profit.

- Fourthly, in cases when the choice of the enterprise responsible for rendering services of general interest was not made according the procedure of public contracting, the level of the necessary compensation should be established after analysing a cost which an average enterprise, adequately equipped and well-managed, would incur in order to meet expectations of the public. The above financial analysis should also take into consideration the turnover and a reasonable margin of profit.

It needs to be stressed that all the above requirements must be fulfilled. Non - compliance with only one of the assumptions indicates that the compensation will be treated as state aid. The omission of the fourth criterion is the most common reason why the support provided was defined as state aid.

The performed analysis of the literature and legal regulations enables to dedunce some important conclusions, particularly it indicates that:

- public aid poses a major threat for the performance of the free market, since, by definition, such support means benefits for entrepreneurs whose activities are supported by public aid, which distorts the free market,

- there are different sorts of public aid so the differentiation which particular sort of aid distorts the free market and which does not is very difficult,

- the legal regulations implemented by the European Commission (in the form of executive or orders) make a necessary element for rationalization of the public aid system. However, in practice, it is difficult to differentiate lawful and unlawful forms of public aid. A large variety of meanings and definitions of the notion: "public aid" arouses many doubts. 
- European regulations where these problems are seen and analyzed, broaden the scope of exemptions from such aid. The reason is a considerable cost of planning and implementation of the projects at the self-government level, which concern common good tasks and services.

\section{ConCLUSIONS}

The references concerning the financing of common good services should not be considered without references to the European Union legislature, especially in the field of public aid and norms concerning the common market. Undoubtedly, the communal services in their broad meaning and the financing realized by territorial self-government units together with the dependent economic entities (communal partnership) and with external entities should be within the EU legal framework, including regulations on public aid and public supply contracts.

Apart from the above, it needs to be stressed that the EU guidelines, should be taken into consideration only with regard to the specifics of a particular member state and only with reference to its economic problems and regional conditions, including interventionism in those fields which feature considerable disproportions in economic development, or where appear specific conditions in which some services can not be rendered in a proper way by the market. Regulations concerning protection of free competition resulting from the EU laws, dealing with interventionism in particular sectors, should be considered with respect to the guidelines for internal market policies and after analysis of abilities to meet the needs of the population in the scope outlined in the social contract.

\section{REFERENCES}

Birkland, T.A. (2016). An Introduction to the Policy Process Theories, Concepts, and Models of Public Policy Making. 4th Edition. New York: Routledge.

Brzozowska, K., Gorzałczyńska-Koczkodaj, M., Kogut-Jaworska, M., \& Zioło, M. (2013). Gospodarka finansowa $w$ jednostkach samorządu terytorialnego. (Financial management in territorial self-government units.) Warszawa: CeDeWu.

European Commission (2003). Sprawa C-280/00 Altmark Trans GmbH i Regierungspräsidium Magdeburg przeciwko Nahverkehrsgesellschaft Altmark GmbH [2003] Rec. I-7747 (Case C-280/00 Altmark Trans GmbH and Regierungsprasidium Magdeburg against Nahverkehrsgesellschaft Altmark GmbH.) za: Komunikat Komisji w sprawie 
stosowania reguł Unii Europejskiej w dziedzinie pomocy państwa w odniesieniu do rekompensaty z tytułu usług świadczonych w ogólnym interesie gospodarczym (2012/C 8/02).

Godfrey, M. (2001). What Works: Evidence-based Policy and Practice in Public Services. Health \& Social Care in the Community, 9(6), 504-505. http://dx.doi.org/10.1046/ j.0966-0410.2001.10281.x.

Jastrzębska, M. (2012). Finanse jednostek samorządu terytorialnego. (Finances of territorial self-government units.) Warszawa: Wolters Kluwer.

Kańduła, S. (2017). The Efficiency of Fiscal Equalization. The Case Study of Municipalities in Poland. Lex localis - Journal of Local Self-Government, 15(4), 803-825. http:// dx.doi.org/10.4335/15.4.803-825(2017).

Kuhlmann, S., \& Fedele, P. (2010). New public management in continental Europe. In H. Wollmann, G. Marcou (Eds.). The Provision of Public Services in Europe. Between State, Local Government and Market. Cheltenham: Edward Elgar Publishing. http:// dx.doi.org/10.4337/9781849807227.

Marcou, G. (2016). The Impact of EU Law on Local Public Service Provision: Competition and Public Service. In H. Wollmann, I. Koprić, G. Marcou (Eds.). Public and Social Services in Europe. From Public and Municipal to Private Sector Provision. Basingstoke: Palgrave Macmillan. http://dx.doi.org/10.1057/978-1-137-57499-2_2.

Maśloch, G., \& Sierak, J. (Eds.) (2013). Gospodarka i finanse samorzq̨du terytorialnego. (Economy and finance of the territorial self-government). Warszawa: Szkoła Główna Handlowa - Oficyna Wydawnicza.

NIK (2015). Realizacja zadań publicznych przez spółki tworzone przez jednostki samorzadu terytorialnego. Informacja o wynikach kontroli NIK. (Supreme chamber of Control Realization of public tasks by territorial self-government partnerships. Information on the outcome of the NIK control.) KGP-4101-002-00/2014. Nr ewid. 13/2014/p/14/019/KGP, NIK.

Official Journal of the EU C 8 of 11/01/2012.

Official Journal of the EU L7 of 11/01/2012.

Patrzałek, L. (2010). Finanse samorzadu terytorialnego. (Finances of the territorial self-government.) Wrocław: Wydawnictwo Uniwersytetu Ekonomicznego we Wrocławiu.

Ross, A.D. (2014). Local Disaster, Resilience Administrative and Political Perspectives (Routledge Research in Public Administration and Public Policy). 1st Edition. New York: Routledge.

Services of General Interest in Europe, 96/C 281/03, European Commission, OJ C 281, 26.09.1996.

Sierak, J., \& Górniak, R. (2011). Ocena efektywności i finansowanie projektów inwestycyjnych jednostek samorządu terytorialnego współfinansowanych funduszami Unii Europejskiej. (Efficiency assessment and financing of investment projects in the territorial self-government units, co-financed by the European Union funds.) Warszawa: Szkoła Główna Handlowa - Oficyna Wydawnicza.

Stiglitz, J.E., \& Rosengard, J.K. (2015). Economics of the Public Sector (Fourth Edition). New York: W. W. Norton \& Company. 
Swianiewicz, P. (2011). Finanse samorzqdowe: koncepcje, realizacja, polityki lokalne. (Self-governmental finances: concepts, realisation, local policies.) Warszawa: Municipium.

Tsekosand, T.N., \& Triantafyllopoulou, A. (2016). From Municipal Socialism to the Sovereign Debt Crisis: Local Services in Greece 1980-2015. In H. Wollmann, I. Koprić, G. Marcou (Eds.). Public and Social Services in Europe. From Public and Municipal to Private Sector Provision. Basingstoke: Palgrave Macmillan. http://dx.doi. org/10.1057/978-1-137-57499-2_10.

UOKIK (2016). Raport o pomocy publicznej w Polsce udzielonej przedsiębiorcom $w 2015$ roku. (Report on public aid for entrepreneurs in Poland in 2015.) Warszawa. http:// uokik.gov.pl (accessed: 20.04.2018).

Ustawa z 27 sierpnia 2009 r. o finansach publicznych (Dz. U. 2017, poz. 2077). (Parliamentary Act of 27/08/2009 on public finance. Journal of laws: of the Republic of Poland, 2017, item 2077).

West, J., Berman, E.M., Bowman, J.S., \& Van Wert, M.R. (2015). Human Resource Management in Public Service: Paradoxes, Processes, and Problems. Fifth Edition. Thousand Oaks: Sage Publications.

Wollmann, H. (2014). Public Services in European Countries: Between Public/Municipal and Private Sector Provision - and Reverse? In C.N. Silva, J. Bucek (Eds.). Fiscal Austerity and Innovation in Local Governance in Europe. New York: Routledge.

Yurchenko, Y., \& Lethbridge, J. (2014). Shared Services - Setting unrealistic expectations, working paper, http://www.psiru.org/publications4658.html?page=2 (accessed: 25.03.2018).

Ząbkowicz, J. (2016). Usługi użyteczności publicznej jako instrument inwestowania $w$ długoterminowe zdolności rozwojowe i globalnq konkurencyjność Unii Europejskiej. Ekonomia XX Wieku. (Services of common good as an instrument of investment in longterm development opportunities and in global competitiveness of the European Union. Economics of the XXI Century.) Wrocław: Wydawnictwo Uniwersytetu Ekonomicznego we Wrocławiu. http://dx.doi.org/10.15611/e21.2016.2.08.

(www1) OECD, http://www.oecd.org (accessed: 20.04.2018). 